\title{
Prescriber-led practice changes that can bolster antimicrobial stewardship in community health care settings
}

\author{
Jerome A Leis ${ }^{1,2,3 \star}$, Karen B Born ${ }^{3}$, Olivia Ostrow ${ }^{4,5}$, Andrea Moser ${ }^{6,7}$, Allan Grill7,8
}

\section{Abstract}

Stabilizing the emerging resistance of antibiotics depends on our ability to practise appropriate antimicrobial stewardship (AMS). Over $90 \%$ of antibiotics dispensed for human use are prescribed in community health care settings rather than in hospitals, with the main prescribers being family physicians, dentists, pharmacists and nurse practitioners working across a broad range of private offices, family health teams, urgent care clinics, emergency departments and long-term care homes. To improve the reach of AMS in community health care settings, the Public Health Agency of Canada partnered with Choosing Wisely Canada in 2017 to develop a focused campaign titled Using Antibiotics Wisely. This campaign is led by the prescribers of antibiotics themselves, who work in community health care settings and are better equipped to identify the specific changes that would support more appropriate use of antibiotics. This article describes these practice changes, the strengths and challenges of Using Antibiotics Wisely and future opportunities to further advance AMS across community health care settings.

Suggested citation: Leis JA, Born KB, Ostrow O, Moser A, Grill A. Prescriber-led practice changes that can bolster antimicrobial stewardship in community health care settings. Can Commun Dis Rep 2020;46(1):1-5. https://doi.org/10.14745/ccdr.v46i01a01

Keywords: antimicrobial stewardship, respiratory infection, urinary tract infection, quality improvement, primary care, long-term care
This work is licensed under a Creative Commons Attribution 4.0 International License.

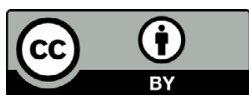

Affiliations

${ }^{1}$ Division of Infectious Diseases and General Internal Medicine, Sunnybrook Health Sciences Centre, Toronto, ON

2 Department of Medicine and Centre for Quality Improvement and Patient Safety, University of Toronto, Toronto, ON

${ }^{3}$ Institute of Health Policy, Management \& Evaluation, Dalla Lana School of Public Health, Faculty of Medicine, University of Toronto, Toronto, ON

${ }^{4}$ Division of Pediatric Emergency Medicine, The Hospital for Sick

Children, Toronto, ON

${ }^{5}$ Department of Pediatrics, University of Toronto,

Toronto, ON

${ }^{6}$ Division of Family Medicine, Baycrest Health Sciences, Toronto, ON

${ }^{7}$ Department of Family and Community Medicine, University of Toronto, Toronto, ON

${ }^{8}$ Department of Family Medicine, Markham Stouffville Hospital, Markham, ON

\section{${ }^{\star}$ Correspondence:}

jerome.leis@sunnybrook.ca

\section{Introduction}

Stabilizing the emerging resistance of antibiotics depends on our ability to practise appropriate antimicrobial stewardship (AMS). In 2015, Canadians filled over 25 million antibiotic prescriptions-or $33 \%$ more than other Organization for Economic Cooperation and Development (OECD) countries such as the Netherlands, Sweden and Germany (1). AMS programs have existed in Canadian acute care hospitals for over 10 years and have been an Accreditation Canada Required Organizational Practice since 2013 (2). Yet 92\% of antibiotics dispensed for human use are prescribed in community health care settings rather than in hospitals (3), with the main prescribers being family physicians, dentists, pharmacists and nurse practitioners working across a broad range of private offices, family health teams, urgent care clinics, emergency departments and long-term care homes. Coordinating a national effort to promote AMS across these community-based professions and practice settings spanning different provinces and territories is a formidable challenge.

To improve the reach of AMS in community health care settings, the Public Health Agency of Canada partnered with Choosing 
Wisely Canada in 2017 to develop a focused campaign titled Using Antibiotics Wisely. This campaign has targeted practice change around two clinical syndromes: respiratory tract infection (RTI) in primary care, and urinary tract infection (UTI) in longterm care. The strongest evidence for inappropriate antibiotic prescription is in these practices.

The objective of this article is to describe these practice changes, the strengths and challenges of Using Antibiotics Wisely and future opportunities to further advance AMS across outpatient health care settings.

\section{Enabling practice change}

Changing antibiotic prescribing in community practices requires stronger engagement of prescribers in the process. This engagement is considered crucial for success; simply being told to change by experts does not result in change (4). Most unnecessary antibiotic use is not related to gaps in knowledge, but rather to other provider-level factors, patient factors and contextual factors (5). For instance, a clinician generally knows that viral rhinosinusitis does not require antibiotics but may decide to prescribe antibiotics if faced with diagnostic uncertainty about whether there is a secondary bacterial infection or if influenced by the perception that a patient is expecting a prescription for antibiotics.

The Theoretical Domains Framework and the behavior change wheel (BCW), a well-recognized model for understanding the determinants of behaviour, has been applied to antibiotic prescribing. Many domains, aside from the knowledge domain, are believed to drive antibiotic prescribing behaviour; these include social influence, environmental context and resources, and beliefs about consequences (6). The challenge has been to identify the specific interventions within these domains that will best target these issues and support practice improvements.

The Using Antibiotics Wisely campaign was established to be led by prescribers of antibiotics who work in community health care settings, that is, those who are better equipped to identify the challenges and associated key changes that would support more appropriate use of antibiotics. The College of Family Physicians of Canada (CFPC), with Choosing Wisely Canada, has played an important role in engaging family physicians in discussions to develop "practice change statements" related to the management of RTI and UTI (Table 1). In the process, Using Antibiotics Wisely uncovered a better understanding of the barriers to AMS and developed clinical approaches that are practical and feasible to implement.

\section{Respiratory infection in primary care}

Between $30 \%$ and $50 \%$ of antibiotic prescriptions for RTI in community practices are unnecessary. This proportion accounts
Table 1: Clinical tools that support practice change in antibiotic prescribing for respiratory tract infection in primary care

\begin{tabular}{|c|c|c|}
\hline Syndrome & $\begin{array}{l}\text { When are antibiotics } \\
\text { indicated? }\end{array}$ & $\begin{array}{l}\text { Tool or clinical } \\
\text { approach to } \\
\text { support practice } \\
\text { change }\end{array}$ \\
\hline $\begin{array}{l}\text { Uncomplicated } \\
\text { otitis media }\end{array}$ & $\begin{array}{l}\text { For vaccinated individuals } \geq 6 \\
\text { months, either a perforated } \\
\text { tympanic membrane with } \\
\text { purulent discharge or a bulging } \\
\text { tympanic membrane with one } \\
\text { of the following criteria: } \\
\text { - Fever }\left(\geq 39^{\circ} \mathrm{C}\right) \\
\text { - Moderately or severely ill } \\
\text { - Significant symptoms lasting } \\
>48 \text { hours }\end{array}$ & $\begin{array}{l}\text { Patient resources } \\
\text { Reassessment as } \\
\text { needed or delayed } \\
\text { prescription }\end{array}$ \\
\hline $\begin{array}{l}\text { Uncomplicated } \\
\text { pharyngitis }\end{array}$ & $\begin{array}{l}\text { Patient's modified Centor } \\
\text { score is } \geq 2 \text { AND throat swab } \\
\text { culture (or rapid antigen test if } \\
\text { available) confirms presence of } \\
\text { group A streptococcus }\end{array}$ & $\begin{array}{l}\text { Viral prescription } \\
\text { Throat swab not } \\
\text { indicated if Centor } \\
\text { score } \leq 1\end{array}$ \\
\hline $\begin{array}{l}\text { Uncomplicated } \\
\text { sinusitis }\end{array}$ & $\begin{array}{l}\text { Symptoms have persisted } \\
\text { for }>7-10 \text { days without } \\
\text { improvement } \\
\text { Antibiotics should only be } \\
\text { considered if the patient has at } \\
\text { least } 2 \text { of the PODS symptoms, } \\
\text { one of those being O or D, } \\
\text { AND the patient meets one of } \\
\text { the following criteria: } \\
\text { - The symptoms are severe } \\
\text { - The symptoms are mild to } \\
\text { moderate, with no response } \\
\text { after a } 72 \text {-hour trial with } \\
\text { nasal corticosteroids }\end{array}$ & $\begin{array}{l}\text { Viral prescription } \\
\text { Reassessment as } \\
\text { needed or delayed } \\
\text { prescription }\end{array}$ \\
\hline $\begin{array}{l}\text { Upper } \\
\text { respiratory } \\
\text { infection } \\
\text { (common cold) }\end{array}$ & $\begin{array}{l}\text { No role unless clear evidence } \\
\text { of secondary bacterial infection }\end{array}$ & Viral prescription \\
\hline $\begin{array}{l}\text { Influenza-like } \\
\text { illness }\end{array}$ & $\begin{array}{l}\text { No role unless clear evidence } \\
\text { of secondary bacterial infection }\end{array}$ & Viral prescription \\
\hline Pneumonia & $\begin{array}{l}\text { Chest x-ray, where available, } \\
\text { showing pneumonia. } \\
\text { (Physical examination alone, } \\
\text { demonstrating respiratory } \\
\text { crackles, is not sufficient to } \\
\text { establish a diagnosis) }\end{array}$ & $\begin{array}{l}\text { Chest x-ray only } \\
\text { if indicated by } \\
\text { physical exam } \\
\text { Patients with } \\
\text { no vital sign } \\
\text { abnormalities } \\
\text { and a normal } \\
\text { respiratory } \\
\text { examination are } \\
\text { unlikely to have } \\
\text { pneumonia and do } \\
\text { not need a chest } \\
\text { x-ray }\end{array}$ \\
\hline $\begin{array}{l}\text { Bronchitis/ } \\
\text { asthma/ } \\
\text { Bronchiolitis }\end{array}$ & $\begin{array}{l}\text { No role unless clear evidence } \\
\text { of secondary bacterial infection }\end{array}$ & $\begin{array}{l}\text { Consider steroids } \\
\text { and short-acting } \\
\text { bronchodilators }\end{array}$ \\
\hline $\begin{array}{l}\text { Acute } \\
\text { exacerbation } \\
\text { of Chronic } \\
\text { Obstructive } \\
\text { Pulmonary } \\
\text { Disease }\end{array}$ & $\begin{array}{l}\text { Clear increase in sputum } \\
\text { purulence with either increase } \\
\text { in sputum volume and/or } \\
\text { increased dyspnea }\end{array}$ & $\begin{array}{l}\text { Consider steroids } \\
\text { and short-acting } \\
\text { bronchodilators }\end{array}$ \\
\hline
\end{tabular}

Source: Table adapted from Choosing Wisely Canada's The 'Cold' Standard Toolkit (7) 
for nearly half of the antibiotics prescribed in family physician offices (8). The first step of the Using Antibiotics Wisely campaign used focus groups of family physicians, pharmacists and nurse practitioners in-person and via teleconference to identify specific practices that need to change in the current management of RTI in primary care. These "Practice Change Statements" include specific guidance about how to reduce antibiotic use for eight specific syndromes in primary care practice. The CFPC has disseminated the statements to all family physicians in Canada via their accredited medical journal Canadian Family Physician (9). For example, antibiotics for pneumonia should not be prescribed based on physical examination findings alone but be based on a chest radiograph whenever available. Throat swabs should only be performed for those patients who meet criteria based on validated clinical predictive scores, and antibiotics given only to those who test positive for group A streptococcus (10).

A significant focus of the Using Antibiotics Wisely campaign has been to identify the key barriers preventing these practice changes. Perceptions about time constraints and patient expectations have been frequently cited reasons for not following best AMS practices $(5,11)$. Building on the work of Meeker et al., the Using Antibiotics Wisely campaign has promoted the use of easily visible posters in family physician offices that can act as a behavioral nudge by aligning patient and physician expectations about using antibiotics judiciously (12).

For patients with a viral RTI who have distressing symptoms and are looking for relief, a "viral prescription pad" can be used to outline the diagnosis, symptom management and evidence-based supportive therapies that do not include antibiotics (13). Finally, where there is diagnostic uncertainty about whether the patient has a viral or bacterial RTI, the use of a delayed prescription has been demonstrated to decrease antibiotic use by $55 \%$ while still maintaining patient satisfaction $(14,15)$.

\section{Urinary tract infection in long-term care homes}

Approximately $50 \%-70 \%$ of long-term care residents in Canada receive at least one antimicrobial agent annually (16). The most common indication is for a UTI $(17,18)$. Overdiagnosis and treatment of UTI in long-term care is well recognized, with at least half of antibiotic prescriptions for this indication considered unnecessary (19).

Antibiotic prescribing for UTI in long-term care is complex and involves interplay between residents, substitute decision-makers and health care providers. Data from Ontario suggest that antibiotic prescribing practices vary widely across long-term care institutions and between providers $(20,21)$. This variability in practice is not explained by differences in patient characteristics; the most significant predictor appears to be the prescriber. One important driver of antibiotic prescribing appears to be the divergent practices in urine culture orders, which are associated with higher antibiotic use and rates of Clostridium difficile infection (22).

There is a great need to have long-term care providers share practice behaviours to better understand the reasons for this variability in urine culture ordering and antibiotic prescribing. The Using Antibiotics Wisely campaign mobilized the CFPC, the Long Term Care Medical Directors Association of Canada and the Canadian Nursing Association (CNA) (23). Following in-person and teleconference focus groups, "practice change statements" for UTI in long-term care were developed to address nine steps that lead to unnecessary antibiotic prescriptions and to identify the role that different health care providers can play to support practice change.

Some of these statements address outdated, institutionally driven policies such as the use of admission order sets that include periodic screening of urine cultures. Other statements relate to assessments for changes in resident health status and the need to consider alternate, more common explanations aside from a UTI. These "practice change statements" also extend beyond long-term care because overdiagnosis of UTI among residents transferred to emergency departments of acute care hospitals can greatly affect resident and substitute decisionmakers' expectations. There is also advice on ways to engage substitute decision-makers when they request urine culture tests in situations that do not fit with recommended criteria.

The optimal interventions to support these practice change statements are not yet known. Many organizations across Canada, for example, Alberta Health Services, Public Health Ontario and the Association of Medical Microbiology and Infectious Diseases, have developed tools to reduce overdiagnosis and subsequent overtreatment of UTI (24-26). One common theme is the need for an objective, standardized approach to the diagnosis of UTI in the long-term care resident population using evidence-based criteria so that all health care providers, patients and substitute decision-makers are aligned in their definition of UTI (27).

\section{Challenges and future opportunities}

While the Using Antibiotics Wisely campaign has helped to engage community-based clinicians in AMS, significant challenges remain. Despite creating practical resources that can be used at the point of care, community-based prescribers still need to be motivated to adopt these practice changes and balance this clinical priority among many others.

One way to incentivize practice change is by providing Continued Medical Education (CME) credits to those who undertake quality improvement projects to improve their antibiotic prescribing. The Using Antibiotics Wisely campaign, in partnership with the CFPC, has provided opportunity for 
such credits through the development of a toolkit that family physicians can use to implement changes that support better management of RTI (7). This toolkit provides ways of integrating tools like the viral prescription pad into the electronic medical record making it easier to integrate into workflow and measure its use over time.

Provider-level feedback on antibiotic use, especially when paired with peer comparison, can also motivate clinicians to adopt these practices (28). The Ontario Program To Improve AntiMlcrobial USE (OPTIMISE) trial is a promising study combining the use of physician-specific reports on antibiotic prescribing in Ontario paired with the resources from the Using Antibiotics Wisely campaign to reduce antibiotic use for management of RTI (29). This randomized controlled trial launched in 2018 and recruited 3,500 of the primary care physicians in Ontario who prescribed the most antibiotics to receive a feedback letter containing different ideas on how to improve their practice. The primary outcome will be the rate of antibiotic prescribing over 12 months following this intervention.

\section{Conclusion}

Antibiotics are being overused to treat RTIs and UTIs, and collaborative efforts among community-based health care providers are needed to address this global problem. Building evidence-based, practical tools for patients and clinicians that target the barriers to change has the potential to improve AMS in outpatient and long-term care settings. Further research on the impact of the Using Antibiotics Wisely campaign related to health outcomes is underway and will help determine the scalability of such initiatives.

\section{Authors' statement}

$\mathrm{JAL}$ - Project conception, literature searches, writing, original draft, review, editing

$\mathrm{KBB}$ - Literature searches, writing, original draft, review, editing

OO - Review, editing

AM - Review, editing

AG - Review, editing

\section{Conflict of interest}

None.

\section{Acknowledgements}

The authors would like to acknowledge D Day, Project Manager, Pan Canadian Initiatives, Choosing Wisely Canada for her assistance with the preparation of this manuscript and development of content related to Using Antibiotics Wisely.

\section{Funding}

A Grill has received remuneration from the College of Family Physicians of Canada (CFPC). JA Leis, KB Born, O Ostrow and $A$ Moser have received remuneration for their roles in the "Choosing Wisely Canada" campaign.

\section{References}

1. Canadian Institute for Health Information. Infographic: Do you need that antibiotic? Ottawa (ON): Canadian Institute for Health Information; 2017 (Accessed 2019-08-30). https:// www.cihi.ca/en/infographic-do-you-need-that-antibiotic

2. Pammett RT, Ridgewell A. Development of an antimicrobial stewardship program in a rural and remote health authority. Can J Hosp Pharm 2016 Jul-Aug;69(4):333-4. DOI PubMed

3. Canadian Antimicrobial Resistance Surveillance System 2017 Report. Ottawa (ON): Public Health Agency of Canada; 2018 (Accessed 2019-08-30). http://publications.gc.ca/collections/ collection_2018/aspc-phac/HP37-21-2017-eng.pdf

4. Sanchez GV, Fleming-Dutra KE, Roberts RM, Hicks LA. Core elements of outpatient antibiotic stewardship. MMWR Recomm Rep 2016;65(6):1-12. DOI

5. McKay R, Mah A, Law MR, McGrail K, Patrick DM. Systematic Review of Factors Associated with Antibiotic Prescribing for Respiratory Tract Infections. Antimicrob Agents Chemother 2016 Jun;60(7):4106-18. DOI PubMed

6. Courtenay M, Rowbotham S, Lim R, Peters S, Yates K, Chater A. Examining influences on antibiotic prescribing by nurse and pharmacist prescribers: a qualitative study using the Theoretical Domains Framework and COM-B. BMJ Open 2019 Jun;9(6):e029177. DOI PubMed

7. The Cold Standard Toolkit. Choosing Wisely Canada. (Accessed 2019-11-06). https://choosingwiselycanada.org/ perspective/the-cold-standard/

8. Silverman M, Povitz M, Sontrop JM, Li L, Richard L, Cejic S, Shariff SZ. Antibiotic prescribing for nonbacterial acute upper respiratory infections in elderly persons. Ann Intern Med 2017 Jun;166(11):765-74. DOl PubMed

9. Choosing Wisely Canada. Using Antibiotics Wisely campaign. Toronto (ON): Choosing Wisely Canada; 2017 (Accessed 2019-08-30). https://choosingwiselycanada.org/ campaign/antibiotics/

10. Fine AM, Nizet $V$, Mandl KD. Large-scale validation of the Centor and Mclsaac scores to predict group A streptococcal pharyngitis. Arch Intern Med 2012 Jun;172(11):847-52. DOI PubMed

11. Linder JA, Singer DE, Stafford RS. Association between antibiotic prescribing and visit duration in adults with upper 
respiratory tract infections. Clin Ther 2003 Sep;25(9):241930. DOI PubMed

12. Meeker D, Knight TK, Friedberg MW, Linder JA, Goldstein NJ, Fox CR, Rothfeld A, Diaz G, Doctor JN. Nudging guideline-concordant antibiotic prescribing: a randomized clinical trial. JAMA Intern Med 2014 Mar;174(3):425-31. DOI PubMed

13. Antimicrobial Stewardship Program. Saskatoon (SK): Saskatchewan Health Authority; 2018 (Accessed 2019-08-30). http://www.rqhealth.ca/departments/ antimicrobial-stewardship-program

14. Plachouras D, Hopkins S. Antimicrobial stewardship: we know it works; time to make sure it is in place everywhere. Cochrane Database Syst Rev 2017 Feb;2(2):ED000119. DOI PubMed

15. Little P, Moore M, Kelly J, Williamson I, Leydon G, McDermott L, Mullee M, Stuart B; PIPS Investigators. Delayed antibiotic prescribing strategies for respiratory tract infections in primary care: pragmatic, factorial, randomised controlled trial. BMJ 2014 Mar;348:g1606. DOI PubMed

16. Daneman N, Campitelli MA, Giannakeas V, Morris AM, Bell CM, Maxwell CJ, Jeffs L, Austin PC, Bronskill SE. Influences on the start, selection and duration of treatment with antibiotics in long-term care facilities. CMAJ 2017 Jun;189(25):E851-60. DOI PubMed

17. Antibiotic stewardship in nursing homes. Atlanta (GA): Centers for Disease Control and Prevention; 2015 (Accessed 2019-08-30). https://www.cdc.gov/longtermcare/pdfs/ infographic-antibiotic-stewardship-nursing-homes.pdf

18. Lee C, Phillips C, Vanstone JR. Educational intervention to reduce treatment of asymptomatic bacteriuria in long-term care. BMJ Open Qual 2018 Dec;7(4):e000483. DOI PubMed

19. Ajayi T, Radhakrishnan R. Urinary tract infection in older adults in long-term care facilities. CMAJ 2016 Sep;188(12):899. DOI PubMed

20. Daneman N, Bronskill SE, Gruneir A, Newman AM, Fischer HD, Rochon PA, Anderson GM, Bell CM. Variability in antibiotic use across nursing homes and the risk of antibiotic-related adverse outcomes for individual residents. JAMA Intern Med 2015 Aug;175(8):1331-9. DOI PubMed

21. Daneman N, Gruneir A, Bronskill SE, Newman A, Fischer HD, Rochon PA, Anderson GM, Bell CM. Prolonged antibiotic treatment in long-term care: role of the prescriber. JAMA Intern Med 2013 Apr;173(8):673-82. DOl PubMed
22. Brown KA, Daneman N, Schwartz KL, Langford B, McGeer A, Quirk J, Diong C, Garber G. The urine culturing cascade: variation in nursing home urine culturing and association with antibiotic use and C. difficile infection. Clin Infect Dis 2019 Jun;pii:ciz482. DOI PubMed

23. Using Antibiotics Wisely in Long-Term Care. Choosing Wisely Canada. (Accessed 2019-11-06). https:// choosingwiselycanada.org/campaign/antibiotics-ltc/

24. Brown KA, Chambers A, MacFarlane $S$, Langford B, Leung V, Quirk J, Schwartz KL, Garber G. Reducing unnecessary urine culturing and antibiotic overprescribing in long-term care: a before-and-after analysis. CMAJ Open 2019 Mar;7(1):E174-81. DOI PubMed

25. Pasay DK, Guirguis MS, Shkrobot RC, Slobodan JP, Wagg AS, Sadowski CA, Conly JM, Saxinger LM, Bresee LC. Antimicrobial stewardship in rural nursing homes: impact of interprofessional education and clinical decision tool implementation on urinary tract infection treatment in a cluster randomized trial. Infect Control Hosp Epidemiol 2019 Apr;40(4):432-7. DOI PubMed

26. AMMI Canada. Asymptomatic Bacteriuria: symptom-free pee: let it be. Ottawa (ON): Association of Medical Microbiology and Infectious Disease Canada; 2016 (Accessed 2019-08-30). https://www.ammi.ca/?ID=127

27. Loeb M, Brazil K, Lohfeld L, McGeer A, Simor A, Stevenson K, Zoutman D, Smith S, Liu X, Walter SD. Effect of a multifaceted intervention on number of antimicrobial prescriptions for suspected urinary tract infections in residents of nursing homes: cluster randomised controlled trial. BMJ 2005 Sep;331(7518):669. DOl PubMed

28. Meeker D, Linder JA, Fox CR, Friedberg MW, Persell SD, Goldstein NJ, Knight TK, Hay JW, Doctor JN. Effect of behavioral interventions on inappropriate antibiotic prescribing among primary care practices: a randomized clinical trial. JAMA 2016 Feb;315(6):562-70. DOI PubMed

29. Schwartz K. Providing antibiotic prescribing feedback to primary care physicians: The Ontario Program to Improve AntiMicrobial USE (OPTIMISE). Rockville (MD): US National Library of medicine; 2018 (Accessed 2019-08-30). https:// clinicaltrials.gov/ct2/show/NCT03776383 